IZA DP No. 6693

Immigrants in Risky Occupations

Pia M. Orrenius

Madeline Zavodny

June 2012

Forschungsinstitut zur Zukunft der Arbeit Institute for the Study of Labor 


\title{
Immigrants in Risky Occupations
}

\author{
Pia M. Orrenius \\ Federal Reserve Bank of Dallas \\ and IZA \\ Madeline Zavodny \\ Agnes Scott College \\ and IZA
}

Discussion Paper No. 6693

June 2012

IZA

P.O. Box 7240

53072 Bonn

Germany

Phone: +49-228-3894-0

Fax: +49-228-3894-180

E-mail: iza@iza.org

Any opinions expressed here are those of the author(s) and not those of IZA. Research published in this series may include views on policy, but the institute itself takes no institutional policy positions.

The Institute for the Study of Labor (IZA) in Bonn is a local and virtual international research center and a place of communication between science, politics and business. IZA is an independent nonprofit organization supported by Deutsche Post Foundation. The center is associated with the University of Bonn and offers a stimulating research environment through its international network, workshops and conferences, data service, project support, research visits and doctoral program. IZA engages in (i) original and internationally competitive research in all fields of labor economics, (ii) development of policy concepts, and (iii) dissemination of research results and concepts to the interested public.

IZA Discussion Papers often represent preliminary work and are circulated to encourage discussion. Citation of such a paper should account for its provisional character. A revised version may be available directly from the author. 


\section{ABSTRACT}

\section{Immigrants in Risky Occupations*}

This chapter reviews the economics literature on immigrant-native differentials in occupational risk. It begins by briefly explaining the theory of compensating wage differentials. It then provides a more detailed discussion of the empirical evidence on the subject, which reaches several conclusions. First, immigrants are overrepresented in occupations and industries with higher injury and fatality rates. Second, immigrants have higher work-related injury and fatality rates in some advanced economies, but not all. Finally, most, but not all, immigrants appear to earn risk premiums similar to natives for working in risky jobs. The chapter closes with a discussion of areas where additional research is needed.

JEL Classification: J15, J61, J81

Keywords: immigrants, risky jobs, compensating differentials

Corresponding author:

Madeline Zavodny

Department of Economics

Agnes Scott College

141 E. College Ave.

Decatur, GA 30030

USA

E-mail: mzavodny@agnesscott.edu

\footnotetext{
* Forthcoming in the International Handbook on the Economics of Migration, ed. Amelie Constant and Klaus F. Zimmermann. We thank the editors and an anonymous referee for helpful comments. We also thank Amy Chapman for her excellent research assistance. The opinions expressed herein are those of the authors and do not necessarily reflect the views of the Federal Reserve Bank of Dallas or the Federal Reserve System.
} 


\section{IMMIGRANTS IN RISKY OCCUPATIONS}

\section{INTRODUCTION}

Although immigrants can be found in virtually every occupation across the globe, many immigrants hold “three D” jobs: jobs that are dirty, dangerous, and difficult. Risky jobs may be attractive to immigrants who have low skills, little education and limited fluency in the host country language. These jobs also may pay more than other jobs immigrants would hold in the host country.

A growing literature examines whether immigrants are disproportionately employed in risky jobs, and if so, why. This chapter surveys the literature on immigrantnative differences in occupational risk. After a brief explanation of the economic theory of occupational risk and compensating differentials, this chapter surveys the literature on whether immigrants are disproportionately employed in risky jobs and whether they are more likely than natives to experience work-related injuries or fatalities. It then discusses the limited literature on immigrant-native differences in risk premiums. It closes with a discussion of areas for future research.

\section{ECONOMIC THEORY}

The standard model of efficient labor markets predicts that risky occupations will pay higher wages to compensate workers for incurring more risk. Profit-maximizing employers trade off higher compensation costs and the cost of reducing occupational risk. The result is a concave wage offer curve in which wages increase with occupational risk at a declining rate, as shown in Figure 1. 
Workers view risk as a disamenity and are willing to hold risky occupations only in exchange for higher wages, called "compensating differentials” or risk premiums. Workers' convex indifference curves show the tradeoff between wages and occupational risk. If workers differ in their willingness to bear risk, those who are the most willing to trade off increased risk for higher wages will sort into the riskier occupations. In terms of Figure 1, workers with steeper indifference curves, like $\mathrm{U}_{\mathrm{N}}$, will sort into relatively safe occupations while workers with flatter indifference curves, like $\mathrm{U}_{\mathrm{I}}$, will sort into relatively risky occupations. Workers in riskier jobs will earn a compensating differential or risk premium, $\mathrm{w}\left(\mathrm{R}_{\mathrm{I}}\right)-\mathrm{w}\left(\mathrm{R}_{\mathrm{N}}\right)$.

The standard model posits that all workers face the same wage offer curve. However, there are likely to be different wage offers curves for different types of workers. For example, if employers can assess workers' productivity, less productive workers will face a lower wage offer curve. At every level of job risk, the employer will offer a lower wage to less productive workers. This is equivalent to a downward shift of the wage offer curve. In addition, the wage offer curve may be flatter for some workers. This is the case if some workers impose higher safety costs on the employer at greater occupational risk levels. The wage curve is flatter to offset the higher costs to the employer of reducing occupational risk for such workers.

Workers who both are less productive and impose higher safety costs on the employer at greater occupational risk levels will face a lower and flatter wage offer curve. This situation is illustrated in Figure 2. The flatter the wage offer curve, the smaller the compensating differential for occupational risk. If the wage offer curve is both low and flat enough for some workers, those workers may not earn any 
compensating differential for occupational risk. This situation is illustrated in Figure 2. Workers in riskier occupations earn less than workers in safer occupations, or $\mathrm{w}_{\mathrm{I}}\left(\mathrm{R}_{\mathrm{I}}\right)<$ $\mathrm{w}_{\mathrm{N}}(0)$ as in Figure 2. Hersch and Viscusi (2010) refer to this situation as segmented labor markets.

The model thus far assumed that markets are efficient. In efficient markets, workers have full information about occupational risk. Dávila, Mora and González (2011) discuss another possibility: some workers may underestimate occupational risk. If some workers underestimate occupational risk, and increasingly so for riskier occupations, they think they are on a different wage curve than they actually are. Their perceived wage curve is like the higher, steeper wage offer curve in Figure 2 while their actual wage offer curve is like the lower, flatter curve. Such misperceptions can also result in some workers not earning compensating differentials. The difference from the earlier scenario is that such misperceptions can create rents for employers at the expense of the workers who underestimate occupational risk.

The empirical literature on compensating differentials in the general population is mixed. Reviews by Smith (1979) and Viscusi (1993) conclude that workers earn compensating differentials for the risk of death but that there is little clear evidence that workers earn compensating differentials for less extreme job hazards, such as non-fatal illnesses or injuries.

\section{Implications for Immigrants}

Immigrants may differ from natives in several ways related to the compensating differentials model. First, immigrants may have different tradeoffs between wages and 
risk than natives, on average. Immigrants typically have less human capital and less wealth, which may cause them to be more willing to accept occupational risk in exchange for higher wages. In terms of Figure 1, immigrants may have flatter indifference curves than natives. This is particularly likely to be the case for target earners who migrate temporarily to work. It also may be true of immigrants who have relatively limited labor market opportunities, such as unauthorized immigrants or those with small networks.

Second, immigrants may face different wage offer curves than natives because of higher safety-related costs. Hersch and Viscusi (2010) posit that this is particularly likely to be the case for immigrants with limited fluency in the host country language. It is more expensive for employers to provide safety training to such workers. Safety-related costs also may be higher for immigrants from countries with lower standards of job safety than the host country because those workers may need more training or take too many risks by host country standards.

Third, immigrants may face different wage offer curves than natives as a result of imperfect markets. As noted by Dávila, Mora and González (2011), immigrants may underestimate occupational risk in their host country. This could occur because occupational risk is very high in their home country and so they mistakenly believe that risk is even lower in the host country than it actually is. Alternatively, it could arise from employers deliberately misinforming immigrants about occupational risk. Employers may be more able to mislead immigrants who are not proficient in the host country language, are relatively recent arrivals, are unauthorized, or have smaller networks. Immigrants are thus theoretically more likely to work in risky occupations than natives for a variety of reasons. They may earn smaller compensating differentials for 
doing so or even no compensating differentials at all. This chapter next turns to the empirical evidence on these issues.

\section{EMPIRICAL EVIDENCE}

Recent research in several advanced economies indicates that immigrants are more likely to work in risky occupations than natives. Consistent with this, immigrants experience higher rates of occupational injuries and fatalities than natives in most advanced economies. There are exceptions, however. This section first reviews the evidence in these areas. It then discusses the evidence on the causes of these immigrant-native differences and on whether immigrants and natives earn similar compensating differentials for working in risky occupations.

\section{Immigrant-Native Differences in Occupational Risk}

Studies of immigrant-native differences in occupational risk typically examine whether immigrants work in occupations or industries with higher injury and fatality rates, on average, than natives. This is an indirect measure of occupational risk that reflects the occupational distribution of immigrants and natives.

In the United States, several recent studies show that immigrants work in riskier jobs than natives. Using data from 2003-2005, Orrenius and Zavodny (2009) conclude that immigrants worked in occupations and industries with higher fatality and injury rates than natives. The average immigrant worked in an industry with a 38 percent higher fatality rate than the average native. Using data from the same period, Hersch and Viscusi (2010) similarly conclude that immigrants worked in industries with higher fatality rates 
than natives, on average, using either overall or nativity-specific fatality rates. The difference is concentrated among Mexican immigrants, who worked in sectors with fatality rates 36 to 46 percent higher than non-Mexican immigrants. Consistent with this finding, Dávila, Mora and González (2011) show using data from 1999-2000 that Hispanic immigrant men worked in occupations with higher fatality and injury rates than native-born Hispanic, non-Hispanic white, and non-Hispanic black men.

These findings mark a change from older research on immigrant-native differences in occupational risk in the United States. Using data from 1979-1980, Berger and Gabriel (1991) show that the average immigrant worked in an industry with a 21 percent lower fatality rate than the average native. Using data from 1991, Hamermesh (1998) shows that immigrants did not work in industries with higher injury rates than white natives.

This change in findings coincides with substantial changes in the origin countries of immigrants to the United States and in their average characteristics. The 1965 Immigration and Nationality Act caused immigration to shift from Europe to Latin America and Asia over ensuing decades. The relative position of immigrants in the wage structure worsened (Borjas 1995). The fraction of U.S. immigrants able to speak English well declined, and average educational attainment fell relative to U.S. natives. The unauthorized population increased, swelling from about 2 to 4 million in 1980 (Warren and Passel 1987) to 8.5 to 10 million in 2000 (Costanzo et al. 2002; Hoefer, Rytina and Campbell 2006).

Research indicates that immigrants work in riskier jobs in Canada. Premji et al. (2010) find that the proportion of immigrants working in a job is positively related to the 
job’s risk of injuries and illnesses in Montréal. Smith, Kosny and Mustard (2009) conclude that Canadian immigrants are more likely to be employed in physicallydemanding occupations, putting them at greater risk for work-related injuries.

Research also indicates that immigrants work in riskier jobs than natives in Spain. Solé, Díaz-Serrano and Rodríguez (2010) report that 36 percent of immigrants hold jobs that expose them to risks, compared with 26 percent of natives. Immigrants from Africa, Latin America and the European periphery (non-EU 15 countries) were more likely than Spanish natives to work in risky jobs, while Asian immigrants were less likely. DíazSerrano (2010) concludes that African immigrants work in riskier jobs than Spanish natives in Catalonia, Spain.

\section{Immigrant-Native Differences in Occupational Injuries and Fatalities}

Studies of immigrant-native differences in occupational injuries and fatalities examine whether immigrants experience more such adverse events than natives. Whereas the studies of occupational risk discussed above apply industry- or occupation-specific injury or fatality rates to workers, these studies examine directly whether immigrants are more likely than natives to be injured or killed because of workplace incidents. Some studies analyze official reports of workplace injuries and fatalities while others use data from surveys that ask about work-related injuries.

In the United States, immigrants have higher work-related fatality rates than natives. Loh and Richardson (2004) report that the work-related fatality rate was 33 percent higher among immigrants than the overall rate during 1996-2001. The workplace fatality rate rose among immigrants during the second half of that period while falling 
among natives. Fatalities were particularly high among immigrants from Mexico, accounting for 40 percent of all fatalities to foreign-born workers; Mexico accounts for about 30 percent of U.S. immigrants. Richardson, Ruser and Suárez (2003) note that foreign-born Hispanic workers had higher fatality rates during 1995-2000 than both Hispanic and non-Hispanic native-born workers. Death rates due to workplace homicides were also higher among the foreign-born, particularly among Asians, than among natives (Sincavage 2005).

Some evidence also indicates that immigrants are more likely to experience workrelated injuries than natives in the United States. Hao (2008) finds that immigrants had a 32 percent greater risk of experiencing a nonfatal workplace injury than natives, based on surveys from 1996-2004. Marvasti (2010) reports that official workplace injury rates are higher in U.S. states with higher fractions of workers who are immigrants, particularly Hispanic immigrants. Sinclair, Smith and Xiang (2006) conclude that immigrants were more likely than natives to have experienced a work-related injury that required medical attention, based on data from 2000-2003. However, Zhang et al. (2009) conclude that immigrants were less likely to have experienced a work-related injury that required medical attention during 1997-2005 than U.S. natives. The source of the difference is unclear since both studies use data from the National Health Interview Surveys.

In Canada, Smith and Mustard (2009) conclude that immigrants were not significantly more likely to report having experienced a work-related injury than natives. However, controlling for education and other observable characteristics, recent male immigrants were more likely to report having experienced a work-related injury requiring medical attention than natives. 
In Spain, Ahonen and Benavides (2006) conclude that official reports indicate higher rates of fatal and non-fatal occupational injuries among immigrants than among natives in 2003. In 2005, López-Jacob et al. (2008) estimate that immigrants had a 34 percent higher workplace fatality rate and a 13 percent higher non-fatal workplace injury rate than Spanish natives overall; immigrants' occupational risk was lower than natives’ in construction, commerce, restaurants and hotels, however.

In Australia, the overall rate of work-related fatalities was similar among immigrants and natives, but fatality rates were higher among immigrants than natives in rural (farmers, fishers, hunters, timber getters and related workers) and mining occupations (Corvalan, Driscoll, and Harrison 1994).

Research indicates higher workplace injuries and fatalities in several other advanced economies, although there are exceptions. According to Bollini and Siem (1995), reports indicate higher occupational accident rates among immigrant workers than native workers in France, Germany, the Netherlands, and Switzerland. The European Agency for Safety and Health at Work (2008) reports that immigrant workers have higher workplace accident rates in France, Germany and Spain; in Sweden and Finland, in contrast, studies of specific industries indicate no significant difference between immigrants and natives in the risk of work-related accidents. Wu et al. (1997) conclude that the overall rate of workplace injuries was lower among legal migrant workers in Taiwan than among Taiwanese natives working in the same industries, but higher for female migrant workers than for female natives.

Interestingly, immigrants might be expected to have lower rates of work-related injuries and fatalities than natives because of the "healthy immigrant" effect. Immigrants 
tend to be positively selected in terms of health attributes when they migrate, and they experience negative assimilation towards natives’ health in some countries (Antecol and Bedard 2006). Despite greater exposure to risks at work, immigrants are less likely to become disabled than natives in Spain (Solé, Díaz-Serrano and Rodríguez 2010). The authors note this could be due to the healthy immigrant effect.

\section{Reasons for Immigrant-Native Differences}

There are several reasons why immigrants tend to have higher occupational injury and fatality rates than natives. The simplest explanation is that immigrants are overrepresented in risky occupations, as discussed above. But why, in turn, are immigrants more likely to work in risky jobs? Research has focused on the role of immigrants’ lower levels of human capital and greater willingness to incur risk.

Workers with relatively low levels of human capital are more likely to work in manual labor jobs that involve more risk. Less-educated workers typically have fewer job choices, lower incomes and less wealth. The compensating differentials model predicts that these factors make workers more willing to trade off higher wages for increased job risk. It is therefore not surprising that immigrants are more likely to work in risky jobs and have higher injury and fatality rates in countries in which immigrants have lower average educational attainment than natives. An interesting, relatively unexplored 
question is whether immigrants and natives with similar levels of educational attainment (and other characteristics) have similar levels of occupational risk. ${ }^{1}$

Limited proficiency in the host country language appears to play an important role in immigrants' higher occupational risk. In the United States, limited-English-proficient Hispanic male immigrants work in occupations with higher fatality and injury rates than their English-proficient counterparts (Dávila, Mora and González 2011). In Australia, immigrant workers from non-English-speaking countries have higher work-related mortality rates than immigrants from English-speaking countries or natives, particularly in the first few years after arrival (Corvalan, Driscoll and Harrison 1994). Other research also reports a negative relationship between occupational risk and years since migration in Taiwan (Wu et al. 1997) and in the United States (Hao 2008), which could be due in part to increased proficiency in the host country language over time.

Immigrants also may have different risk preferences than natives, on average, for reasons unrelated to human capital. Immigrants may be less risk averse than natives. After all, the fact that immigrants have chosen to move to another country is consistent with them being less risk averse than their countrymen who stayed behind. However, Bonin et al. (2006, 2009) find that first-generation immigrants in Germany are more risk averse than German natives.

Immigrants who migrate in search of higher earnings may also be more willing to accept greater risk in exchange for higher wages. Interviews with recent migrant workers

\footnotetext{
${ }^{1}$ Orrenius and Zavodny (2009) report that the immigrant-native gap in occupation or industry injury and fatality risks is smaller when controlling for education, language ability and other observable characteristics, but it remains significant for some measures.
} 
in England and Wales suggest that they work in risky sectors and occupations because of the importance they place on earning as much as possible as quickly as possible (McKay, Craw and Chopra 2006). In Spain, the occupation-industry injury and fatality rate is negatively related with job satisfaction among natives but not immigrants (Díaz-Serrano 2010). This is consistent with immigrants being less risk averse than natives.

Alternatively, immigrants and natives may have similar risk preferences but immigrants perceive risks to be lower than natives do. There is little direct evidence on whether immigrants underestimate risk compared with natives. For example, interviews of migrant workers in England and Wales conclude that some interviewees underestimated job risks (McKay, Craw and Chopra 2006), but the study does not include a comparison with natives. The negative relationship between years since migration and occupational risk reported in some studies (Wu et al. 1997; Hao 2008; Orrenius and Zavodny 2009) is consistent with immigrants' estimate of occupational risk becoming more accurate over time as well as with increased fluency in the host country language.

Other market imperfections could also result in immigrants working in riskier jobs. Ethnographic studies conclude that many immigrants, particularly the undocumented, are reluctant to complain about unsafe working conditions because they are concerned about losing their job or being deported or because they are not aware of their rights (e.g., Brown, Domenzain and Villoria-Siegert 2002; Walter et al. 2002;

Ahonen et al. 2009).

\section{Underreporting}

Underreporting is a continual concern in studies of occupational risk. Underreporting is a well-documented phenomenon in the workers' compensation system in the United States 
(e.g., Biddle et al. 1998) and Canada (e.g., Shannon and Loew 2002). Employers have an incentive to underreport payroll and injuries in order to reduce the workers' compensation insurance premiums they have to pay. Employers may give workers paid time off as an incentive to not claim workers' compensation, or employers may threaten to dismiss workers if they file a claim. Work-related injuries, illnesses or fatalities also may not be correctly attributed to work, particularly if the injury, illness or fatality occurs later, such as asbestos exposure that results in cancer after decades.

Underreporting may be higher for immigrants than natives for several reasons. Immigrants may be less likely than natives to report occupational injuries and illnesses, perhaps because they are less aware of their rights or less likely to correctly attribute them to their employment. Alternatively, employers may be better able to discourage immigrants from filing a claim for a work-related injury or illness. In addition, surveys and official statistics will underestimate workplace injuries, illnesses and fatalities among immigrants if they leave the host country after incurring an injury or illness. Lower rates of health insurance coverage among immigrants than natives-an issue in the United States and other countries without universal coverage-also may result in greater underreporting among immigrants if the uninsured are less likely to see a health care provider when injured or ill.

The evidence on whether immigrants underreport work-related injuries and illnesses to their employers is inconclusive. In the United States, between 63 and 71 percent of low-wage, low-skilled immigrant workers surveyed in California and New York who had experienced a work-related injury or illness said they had reported it to a supervisor (Brown, Domenzain and Villoria-Siegert 2002; Gany et al. 2011). Migrant 
workers interviewed in Britain said they often did not report workplace accidents for fear of being dismissed (McKay, Craw and Chopra 2006). A study of recent immigrants in Canada concluded that most, but not all, injured workers reported their injury to a healthcare provider or their employer; many said they were discouraged from filing a workers’ compensation claim or misled by their employer about their rights (Kosny et al. 2011). None of these studies include a comparison to native-born workers, so it is unclear whether immigrants are less likely to report work-related injuries and illnesses than natives.

Some evidence does suggest that immigrants' work-related injuries and illnesses are underreported in official records relative to natives. Recent immigrants to Canada were less likely than natives to report receiving benefits from workers' compensation or other programs after experiencing work-related injury (Smith, Kosny and Mustard 2009). A survey conducted in Trentino, Italy, concluded that immigrants were less likely to officially report occupational injuries than natives, often because their employer did not want them to, because they were employed illegally, or because they feared losing their job (Martinelli 2011).

Higher rates of self-employment may result in greater underreporting of workrelated injuries and illnesses among immigrants. Immigrants are more likely than natives to be self-employed in Canada (Hou and Wang 2011) and the United States (Orrenius and Zavodny 2011), among others. Self-employed workers may fall through the cracks of the workers' compensation system and other official records, particularly if they are day laborers working off the books. 
Finally, immigrant-native differences in occupational risk will be underestimated if immigrants misrepresent their nativity for fear of deportation. This may be particularly true of unauthorized immigrants. Employers who hire unauthorized immigrant workers also may misrepresent workers' nativity because they do not know it or because they are concerned about penalties for hiring such workers.

\section{Compensating Differentials}

Economic theory predicts that workers will earn smaller or even no compensating differentials, or risk premiums, if they impose greater safety costs on employers or work in imperfectly competitive labor markets. Markets might not be perfectly competitive if workers do not have complete information about occupational risk or if employers have some monopsony power over workers, among other reasons. As discussed above, these situations may apply disproportionately to immigrants.

However, some studies of immigrant-native differences in compensating differentials find that immigrants earn larger, not smaller, compensating differentials than natives. The literature to date has only examined the United States. Berger and Gabriel (1991) report that risk premiums are 25 percent higher among immigrants than among natives; immigrants who work in industries with higher fatality rates not only earn more relative to those working in safer industries, but their average return for doing so is 25 percent larger than the corresponding return among natives. Dávila, Mora and González (2011) conclude that limited-English-proficient Hispanic male immigrants earn larger risk premiums than other Hispanic immigrants or U.S. natives for working in occupations 
with higher fatality rates. Hersch and Viscusi (2010) find no significant immigrant-native difference in compensating differentials among most groups of immigrants.

There are cases where immigrants do earn smaller compensating differentials than natives. Dávila, Mora and González (2011) find that English-proficient Hispanic male immigrants incur an earnings penalty—a negative risk premium—for working in jobs with higher fatality rates. Hersch and Viscusi (2010) conclude that immigrants from Africa and Mexico do not earn compensating differentials for working in jobs with higher fatality rates. Their further investigation of Mexican immigrants reveals that those who understand English receive a higher wage premium for fatality risks than those who do not. This is the opposite of Dávila, Mora and González (2011)’s conclusion, warranting further research on this issue.

These results leave it unclear why some groups of immigrants earn larger risk premiums than natives while others - mainly from Mexico, according to Hersch and Viscusi (2010)—earn smaller or no risk premiums. If smaller risk premiums are due to higher safety costs, workers who are not proficient in the host country language would be expected to earn smaller risk premiums. If they are due to market imperfections, workers who are more likely to underestimate risk or be taken advantage of by employers would be expected to earn smaller risk premiums. These circumstances may disproportionately apply to unauthorized immigrants. There is no direct evidence this is the case, however. Dávila, Mora and González (2011) find that Hispanic immigrant males who are not naturalized U.S. citizens earn positive risk premiums. Hersch and Viscusi (2010) report that foreign-born workers who now have U.S. permanent resident status but previously 
were unauthorized immigrants do not earn significantly different risk premiums than other immigrants.

\section{DISCUSSION}

Although there is a growing literature on immigrants and occupational risk, there are several important areas for further research. Researchers need a better understanding of why immigrants are more likely to work in risky jobs in most countries. Do immigrants choose to work in risky jobs because they are less risk averse and simply want to earn higher wages or do limited choices push them into risky jobs? The finding that occupational risk declines with years since migration is consistent with either of these possibilities. Mixed evidence on whether limited-English-proficient Hispanic immigrants earn compensating differentials in the United States also makes it difficult to distinguish between these two possibilities.

It is also important determine whether immigrants earn large enough risk premiums to compensate them for greater occupational risk. The limited evidence suggests that most groups of immigrants do earn compensating differentials for fatality risk, but it is not clear whether these differentials fully compensate them for higher risks. Future research could examine immigrant-native differences in workers' compensation and insurance coverage and how such differences relate to differences in compensating differentials.

There are several other relatively unexplored areas. Do immigrants and natives have similar perceptions of occupational risks? What is the role of networks in immigrants' occupational risk? Within occupations and industries, do employers assign 
immigrants to riskier jobs? Answering the last question would require careful analysis of whether there are systematic differences between immigrants’ occupational risk as measured by overall industry and occupation injury and fatality rates versus immigrants’ actual workplace injury and fatality rates.

Research in this area has focused almost exclusively on the first generation, or people who immigrate. How the second generation, the children of immigrants, compare to the first generation and to natives has received little attention. Bonin et al. $(2006,2009)$ show that in Germany, the second generation has risk attitudes similar to natives. The extent of assimilation in occupational risk both within and across immigrant generations is worthy of additional research.

Another interesting question is whether immigration leads to changes in occupational risk. Do employers decrease safety standards when immigration increases, or does immigration induce changes in the wage structure that make it possible for employers to reduce occupational risk? Research using German data from 1976 concludes that a higher share of foreign guestworkers in a firm is associated with fewer severe accidents among the firm's native workers but has no effect on the number of accidents among the guestworkers within a firm (Bauer et al. 1998). Meanwhile, a higher share of skilled guestworkers is associated with more non-severe accidents among the guestworkers within a firm. Further research on the interaction between immigrant shares, skill levels and occupational risk among both natives and immigrants is needed.

Most research on immigrant-native differences in occupational risk has focused on low-skilled workers. Hersch and Viscusi (2010) restrict their sample to blue-collar jobs, for example. More research on high-skilled immigrants and occupational risk is 
warranted. Skilled immigrants may be at heightened risk for workplace accidents if they experience occupational downgrading after migrating and are not accustomed to manual labor. Skilled immigrants also may take on risk in other ways, such as starting their own business.

Finally, this survey only includes studies on developed countries. Given the high levels of South-South migration, research on immigrants and occupational risks in developing countries is a key area for future research. Occupational risks may be higher in developing countries, and workers may have less access to workers' compensation benefits or health care if they experience work-related injuries or illnesses.

\section{SUMMARY}

This chapter surveys the literature on immigrant-native differentials in occupational risk. Research indicates that immigrants are overrepresented in occupations and industries with higher injury and fatality rates in Canada, Spain and the United States. Immigrants have higher work-related injury and fatality rates in some advanced economies, but not all. Limited proficiency in the host country language appears to play a role in why immigrants are more likely to work in risky jobs in some countries. The limited literature on compensating differentials suggests that most, but not all, immigrants earn risk premiums similar to natives for working in risky jobs. 


\section{REFERENCES}

Ahonen, Emily Q., and Fernando G. Benavides (2006). "Risk of Fatal and Non-fatal Occupational Injury in Foreign Workers in Spain.” Journal of Epidemiology and Community Health 60: 424-426.

Ahonen, Emily Q., Victoria Porthé, María LuisaVázquez, Anna María García, Ma. José López-Jacob, Carlos Ruiz-Frutos, Elena Ronda-Pérez, Joan Benach, and Fernando G. Benavides (2009). "A Qualitative Study about Immigrant Workers' Perceptions of their Working Conditions in Spain.” Journal of Epidemiology and Community Health 63: 936942.

Antecol, Heather, and Kelly Bedard (2006). "Unhealthy Assimilation: Why Do Immigrants Converge to American Health Status Levels?” Demography 43 (May): 337360 .

Bauer, Thomas K., Andreas Million, Ralph Rotte, and Klaus F. Zimmermann (1998). "Immigration Labor and Workplace Safety." IZA Discussion Paper No. 16.

Berger, Mark C., and Paul E. Gabriel (1991). "Risk Aversion and the Earnings of US Immigrants and Natives.” Applied Economics 23: 311-318.

Biddle, Jeff, Karen Roberts, Kenneth D. Rosenman, and Edward M. Welch (1998). "What Percentage of Workers with Work-Related Illnesses Receive Workers' Compensation Benefits?” Journal of Occupational and Environmental Medicine 40:325331.

Bollini, Paola, and Harald Siem (1995). "No Real Progress towards Equity: Health of Migrants and Ethnic Minorities on the Eve of the Year 2000.” Social Science \& Medicine 41: 819-828.

Bonin, Holger, Amelie Constant, Konstantinos Tatsiramos, and Klaus F. Zimmermann (2006). "Ethnic Persistence, Assimilation and Risk Proclivity.” IZA Discussion Paper No. 2537.

Bonin, Holger, Amelie Constant, Konstantinos Tatsiramos, and Klaus F. Zimmermann (2009). “Native-Migrant Differences in Risk Attitudes.” Applied Economics Letters 16: 1581-1586.

Borjas, George (1995). “Assimilation and Changes in Cohort Quality Revisited: What Happened to Immigrant Earnings in the 1980s?” Journal of Labor Economics 13: 201245.

Brown, Marianne P., Alejandra Domenzain, and Nelliana Villoria-Siegert (2002).

"Voices from the Margins: Immigrant Workers' Perceptions of Health and Safety in the 
Workplace.” University of California, Los Angeles Labor Occupational Safety and Health Program Report.

Corvalan, Carlos F., Timothy R. Driscoll, and James E. Harrison (1994). "Role of Migrant Factors in Work-Related Fatalities in Australia." Scandinavian Journal of Work and Environmental Health 20: 364-370.

Costanzo, Joseph M., Cynthia David, Caribert Irazi, Danidel Goodkind, and Roberto Ramirez (2002). “Evaluating Components of International Migration: The Residual Foreign Born.” U.S. Census Bureau, Population Division Working Paper No. 61.

Dávila, Alberto, Marie T. Mora, and Rebecca González (2011). “English-Language Proficiency and Occupational Risk Among Hispanic Immigrant Men in the United States.” Industrial Relations 50 (April): 263-296.

Díaz-Serrano, Luis (2010). "Do Legal Immigrants and Natives Compete in the Labour Market? Evidence from Catalonia.” IZA Discussion Paper No. 4693.

European Agency for Safety and Health at Work (2008). Literature Study on Migrant Workers. http://osha.europa.eu/en/publications/literature_reviews/migrant_workers

Gany, Francesca, Rebecca Dobslaw, Julira Ramierz, Josana Tonda, Iryna Lobach, and Jennfier Leng (2011). "Mexican Urban Occupational Health in the U.S.: A Population at Risk.” Journal of Community Health 36: 175-179.

Hamermesh, Daniel S. (1998). "Immigration and the Quality of Jobs.” Pp. 75-106 in Daniel S. Hamermesh and Frank D. Bean, eds., Help or Hindrance? The Economic Implications of Immigration for African Americans. New York: Russell Sage Foundation.

Hao, Lingxin (2008). "Workplace Nonfatal Injuries Among Immigrants to the U.S." Mimeo, Johns Hopkins University Department of Sociology. Available online at http://paa2008.princeton.edu/download.aspx?submissionId=80386.

Hersch, Joni, and W. Kip Viscusi (2010). “Immigrant Status and the Value of Statistical Life.” Journal of Human Resources 45 (Summer): 749-771.

Hoefer, Michael, Nancy Rytina, and Christopher Campbell (2006). "Estimates of the Unauthorized Immigrant Population Residing in the United States: January 2005.” U.S. Department of Homeland Security, Office of Immigration Statistics.

Hou, Feng, and Shunji Wang (2011). “Immigrants in Self-Employment.” Perspectives on Labour and Income (Statistics Canada) http://www.statcan.gc.ca/pub/75-001x/2011003/article/11500-eng.pdf.

Kosny, Agnieszka, Marni Lifshen, Ellen MacEachen, Peter Smith, Gul Joya Jafri, Cynthia Neilson, Diana Pugliese, and John Shields (2011). "Delicate Dances: Immigrant 
Workers’ Experiences on Injury Reporting and Claim Filing.” Institute for Work and Health www.iwh.on.ca/system/files/at-work/at_work_65.pdf.

Loh, Katherine, and Scott Richardson (2004). "Foreign-born Workers: Trends in Fatal Occupational Injuries, 1996-2001.” Monthly Labor Review 127 (June): 42-53.

López-Jacob, Ma. José, Emily Q. Ahonen, Ana María García, Ángel Gil, and Fernando G. Benavides (2008). “Comparación de las Lesiones por Accidente de Trabajo en Trabajadores Extranjeros y Españoles por Actividad Económica y Comunidad Autónoma.” Revista Española de Salud Pública 82 (March-April): 179-187.

Martinelli, Daniela (2011). "Victims of Occupational Injuries: A Comparison between Migrants and Italians.” Rivista di Criminologia, Vittimologia e Sicurrezza 5 (MayAugust): 101-121.

Marvasti, Akbar (2010). “Occupational Safety and English Language Proficiency.” Journal of Labor Research 31: 332-347.

McKay, Sonia, Marc Craw, and Deepta Chopra (2006). "Migrant Workers in England and Wales: An Assessment of Migrant Worker Health and Safety Risks.” London Metropolitan University, Working Lives Research Institute Report.

Orrenius, Pia M., and Madeline Zavodny (2009). “Do Immigrants Work in Riskier Jobs?” Demography 46 (August): 535-551.

Orrenius, Pia M., and Madeline Zavodny (2011). "From Brawn to Brains: How Immigration Works for America.” Federal Reserve Bank of Dallas Annual Report http://dallasfed.org/fed/annual/2010/ar10.pdf.

Premji, Stephanie, Patrice Duguay, Karen Messing, and Katherine Lippel (2010). “Are Immigrants, Ethnic and Linguistic Minorities Over-represented in Jobs with a High Level of Compensated Risk? Results from a Montréal, Canada Study Using Census and Workers' Compensation Data.” American Journal of Industrial Medicine 53 (September): 875-885.

Richardson, Scott, John Ruser, and Peggy Suárez (2003). "Hispanic Workers in the United States: An Analysis of Employment Distributions, Fatal Occupational Injuries, and Non-fatal Occupational Injuries and Illnesses.” Pp. 43-82 in National Research Council, Safety is Seguridad. Washington, DC: National Academies Press.

Shannon, Harry S., and Graham S. Lowe (2002). "How Many Injures Workers Do Not File Claims for Workers’ Compensation Benefits?” American Journal of Industrial Medicine 42: 467-473.

Sincavage, Jessica R. (2005). “Fatal Occupational Injuries Among Asian Workers.” Monthly Labor Review 128 (October): 49-55. 
Sinclair, Sara A., Gary A. Smith, and Huiyun Xiang (2006). "A Comparison of Nonfatal Unintentional Injuries in the United States Among U.S.-Born and Foreign-Born Persons.” Journal of Community Health 31 (August): 303-325.

Smith, Peter M., Agnieszka A. Kosny, and Cameron A. Mustard (2009). "Differences in Access to Wage Replacement Benefits for Absences Due to Wrok-Related Injury or Illness in Canada.” American Journal of Industrial Medicine 52: 341-349.

Smith, P.M., and C.A. Mustard (2009). "Comparing the Risk of Work-related Injuries between Immigrants to Canada and Canadian-born Labour Market Participants.” Occupational and Environmental Medicine 66 (June): 361-367.

Smith, Robert S. (1979). "Compensating Wage Differentials and Public Policy: A Review.” Industrial and Labor Relations Review 32 (April): 339-352.

Solé, Meritxell, Luis Díaz-Serrano, and Marisol Rodríguez (2010). "Work, Risk and Health: Differences between Immigrants and Natives in Spain.” IZA Discussion Paper No. 5338.

Viscusi, W. Kip (1993). “The Value of Risks to Life and Health.” Journal of Economic Literature 31 (December): 1912-1946.

Walter, Nicholas, Philippe Bourgois, H. Margarita Loinaz, and Dean Schillinger (2002). "Social Context of Work Injury Among Undocumented Day Laborers in San Francisco." Journal of General Internal Medicine 17 (March): 221-229.

Warren, Robert, and Jeffrey S. Passel (1987). "A Count of the Uncountable: Estimates of Undocumented Aliens Counted in the 1980 United States Census.” Demography 24 (August): 375-393.

Wu, Trong-Neng, Saou-Hsing Liou, Chao-Chun Hsu, Show-Lin Chao, Shu-Fen Liou, Kquei-Nu Ko, Wen-Yu Yeh, and Po-Ya Chang (1997). "Epidemiologic Study of Occupational Injuries Among Foreign and Native Workers in Taiwan.” American Journal of Industrial Medicine 31: 623-630.

Zhang, Xiaofei, Songlin Yu, Krista Wheeler, Kelly Kelleher, Lorann Stallones, and Huiyun Xiang (2009). "Work-Related Non-Fatal Injuries Among Foreign-Born and USBorn Workers: Findings from the U.S. National Health Interview Survey, 1997-2005.” American Journal of Industrial Medicine 52: 25-36. 


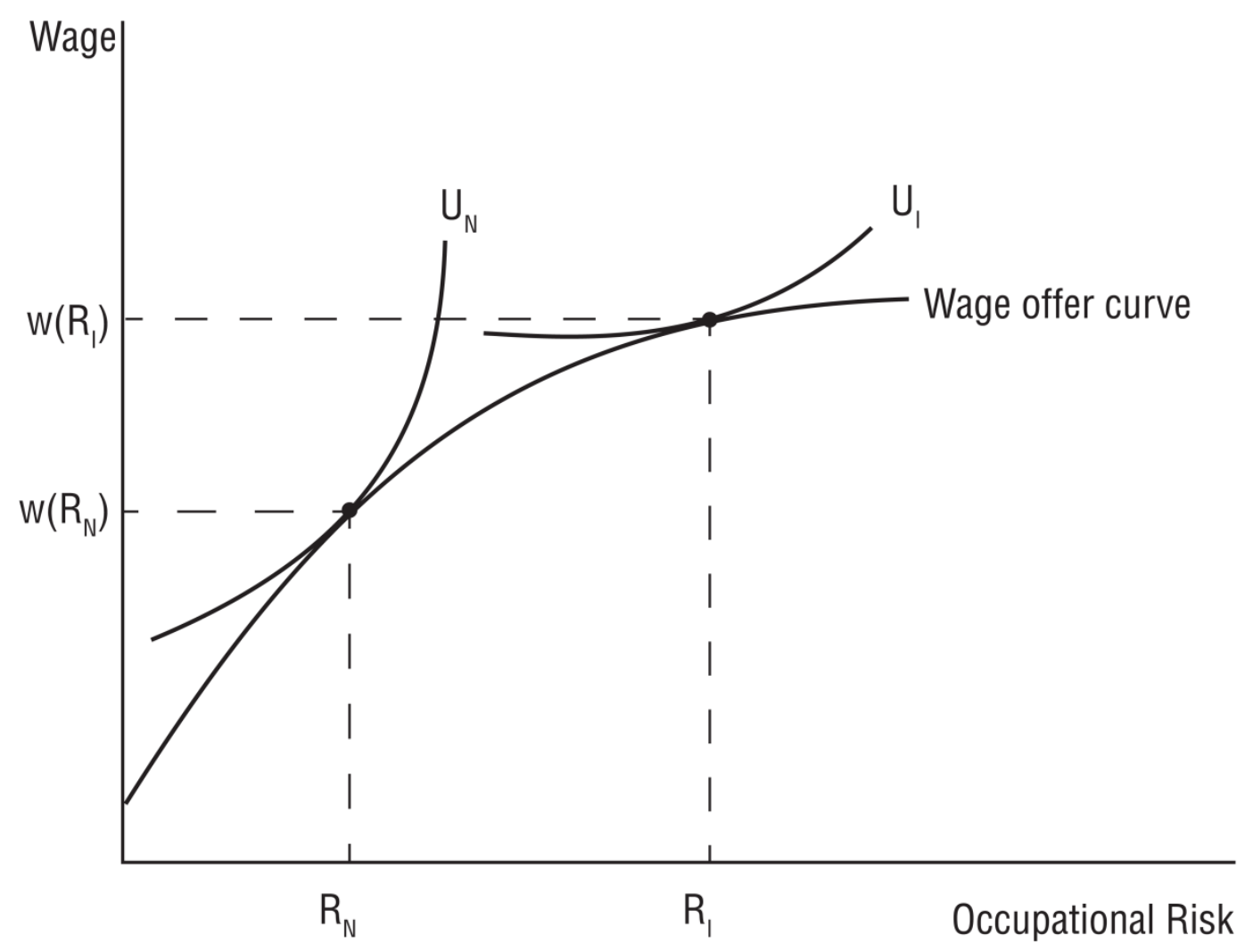

Figure 1.

Wage offer curve and indifference curves for workers with different willingness to bear risk 


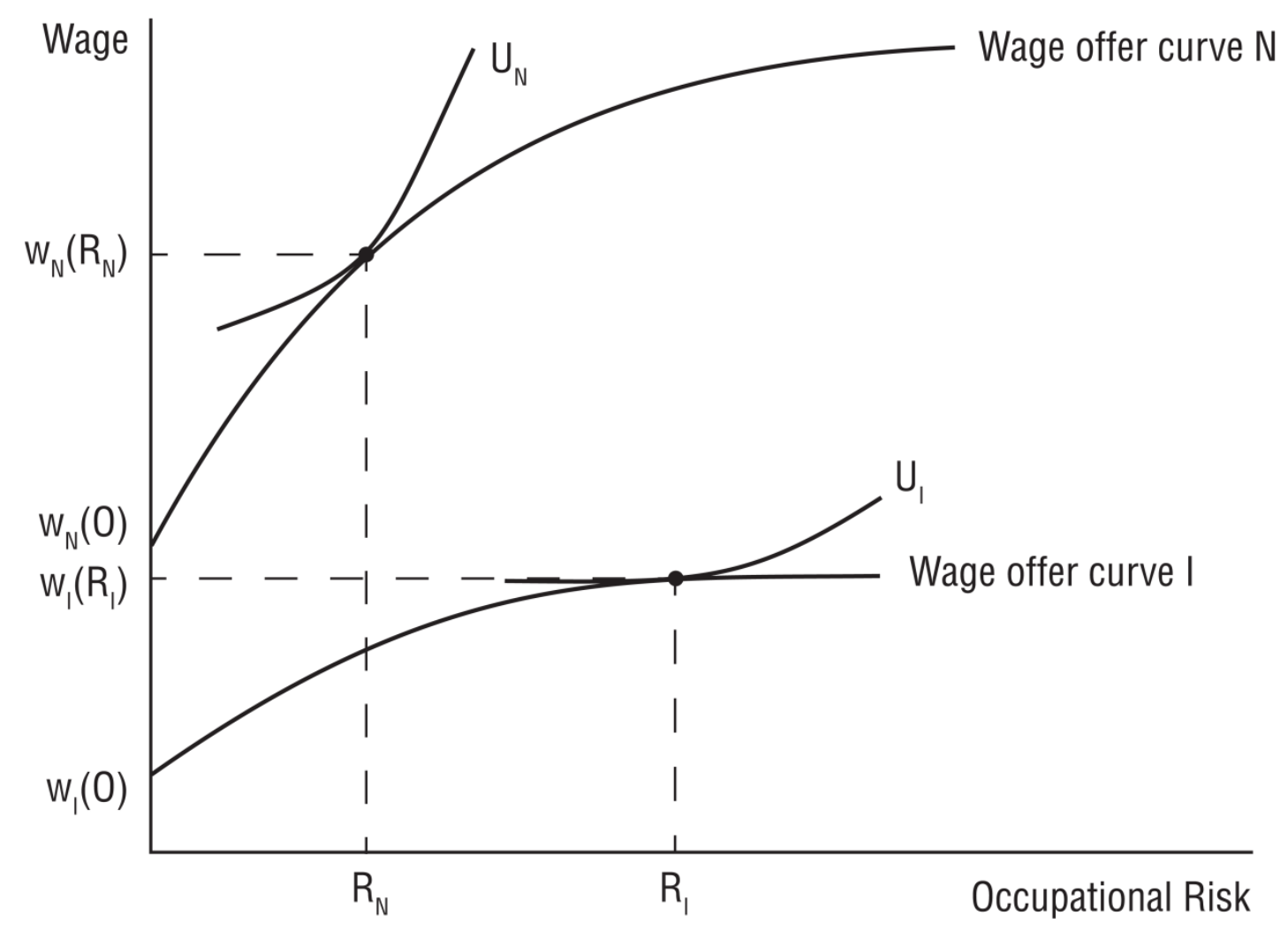

Figure 2.

Different wage offer curves for workers with different cost of reducing risk 